\title{
A Study of Training Managers and Department Managers role in Successful Implementation of E-Learning as training medium in hospitality Industry in India
}

\author{
Renju Mathai \\ International Business and Management Studies, Stenden University \\ PO Box 36037, Doha Qatar \\ E-mail: rmathai@ stenden.eu.qa
}

Received: April 24, 2016 Accepted: May 18, 2016 Published: June 02, 2016

doi:10.5296/ijhrs.v6i2.9462 URL: http://dx.doi.org/10.5296/ijhrs.v6i2.9462

\begin{abstract}
A large number of organizations have shifted, wholly or partially towards using E- Learning as a training tool. Hospitality industry is one such important industry which has already started using E- Learning as a training tool. It is extremely important for hospitality industry to improve the skills and knowledge of their employees where there is a lot of transition globally, so that the industry can keep in pace with the changes happening and attain success in this transition. In spite of being one of the most important industries in India, research in the usage of E- Learning in hospitality industry is extremely limited. The department and training managers of the hotels also play an important role in the successful implementation of E-Learning by rendering support and guidance to the trainees, by which the trainees self-efficacy is boosted to undergo the E-Learning and leads to improvement in performance and efficiency. E-Learning can be used by the management for rapid delivery of information, more reliable and better learning opportunities for employees. This study shows that effective training through E-Learning is one of its robust technologies which will definitely enhance the quality in a faster pace of training the employees in the hospitality sector. This transformation will bring mobility of the corporate managers to be positioned in a centralized location to facilitate and incorporate the best training practices that the hospitality industry is lacking in the proposed region of study. Based on the results and findings it is seen that cost benefit analysis has rated by all the managers for the successful implementation of E-Learning as a training medium. It helps the training manager to explain the productiveness of the training program and leads to the successful implementation of E-Learning as a training medium. By looking into the department managers role, it is seen that analyzing the
\end{abstract}


characteristics of the employees and take into consideration during course design, giving orientation to the trainees at the start of the course and after the updating of course material and responding to the feedback by updating or amending the course material as per the requirement are proven to be the top significant role of the department managers for the successful implementation of E-Learning.

Keywords: Training, Training in Hospitality, E- Learning, Scenario of E- Learning

\section{Introduction}

All the business functions done are to ensure how it plays an important role in the company's success. Knowledgeable employees are an asset for every organization as they can provide real value to customers. Historically, training was considered as an adjunct function of a department but now it has been elevated to an essential feature to meet the competitive business needs. It is a business requirement to be in the success row of the competitive industry. The success of the hospitality industry is not only to satisfy the guests but also, loyalty to the guests, commitment towards exceptional service and quick and precise recovery from problems, which can be achieved by proper training. The main purpose of this study is to provide a better understanding about the successful implementation of E- Learning as a training medium in the hospitality industry as well as, understanding the current scenario of E- Learning in the hospitality industry in India.

\subsection{Significance of study}

The competition in the hospitality industry has shown a great escalation and it has given a new meaning to the success of the hospitality industry. According to the World Travel and Tourism Council 2011, Indian hospitality and tourism industry acquired an extra-ordinary growth of $600 \%$ during the last decade and is predicted to grow rapidly in this decade too. Indian tourism industry is expected to grow $9 \%$ every year and will reach the top 10 by the end of the next decade. According to the Travel and Tourism Competitiveness Report 2011, by the World Economic forum, India stands $12^{\text {th }}$ in Asia Pacific region and $68^{\text {th }}$ in the world (Forty first annual reports 2010-2011), in the list of attractive destinations. Therefore, the increase in investment will create more employment opportunities in the hospitality industry. In spite of this growing trend, there seems to be a shortage in the skilled personnel. Mr. Nataraja, secretary of SHRAI, CEO of GRT (Human resources), says that "getting skilled work force and employee retention are the two biggest problems in this industry."As per the study of Leena Kakkar and Sapna (2012), source of foreign exchange earnings in India through tourism has a great impact on the balance of payment of the country. The Indian tourism industry has generated about US\$ 100 billion in 2008 and later on which is to touch down as an increase of US $\$ 275.5$ billion by 2018 with annual growth rate of $9.4 \%$. There are about 20 million people working in the Indian tourism industry to achieve this target. Because of this, developing countries like India can provide jobs, increase and diversify income by protecting the environment and promote cultural awareness. Mr. Rajeev Menon, Vice President, Marriot, indicates the work force shortage as the single largest problem. The 
gap between the demand and supply of the skilled work force in the hospitality industry is increasing. The ninth five-year plan commission has predicted a shortage of 30,000-trained persons in this industry every year.

\subsubsection{Objectives of Study}

The primary objective of the study is to identify the impact of E- Learning in the Corporate training Process in the hospitality Industry.

A) Identify the role of the training managers in the hospitality industry to facilitate E- Learning in the corporate world from the manager's perspective

B) Identify role of the department managers in the hospitality industry to facilitate E- Learning in the corporate world from the manager's perspective

C) Examine the current scenario of the Industry E- Learning Interaction

\section{Training}

Training is the most expensive intervention in any company. It is an investment in people and improves the bottom line of a company. (Debra and Catherine 2002). Training is said to be one of the most important aspects in the changing technology and market (Chilembwe James Malitoni and Jarvis Baluti 2014).According to Raymond Noe, (2008), "training refers to a planned effort by a company to facilitate employees' learning of job-related competencies."As per the studies of Aravamudhan, R. Krishnaveni (2016) stated that training is identified as of process of upgrading the knowledge, developing skills, bringing about attitude and behavioral changes, and improving the ability of the trainee to perform tasks effectively and efficiently in organization. According to Brinia and Alexandra (2016) has highlighted that ongoing education and training are the result of the urgent need for lifelong learning. They have also mentioned that the obstacle and the difficulty of work in business require new knowledge, skills and qualifications of employees. The in-company training is the framework through which workers can be equipped appropriately.

\subsection{Training in Hospitality}

According to Chon and Sparrowe (2000), hospitality industry is a labor intensive industry which relies on large workforce. This implies that dedication to training is a must for all levels of the workforce. The hospitality industry is undergoing a period of extraordinary transformation with unparalleled opportunity. Enz (2009), comments that time to train, employee morale and lack of employee skills were the main concern for the Hotel Managers where finding top talent for General Manager Position and labor shortage were the primary concern for the Executives. Ferguson, (2008), says that hospitality industry has left in the involvement of more complex work forces which emphasizes the importance of training. The changing business environment, 24 x 7 work schedule, expectations of the guests makes the scheduling of training difficult. Employees of the hospitality industry deal face to face with the customers who can give immediate response as either a compliment or a complaint. Expectation of level and service along with the quality needs differ from each and every individual customer. This in turn creates a satisfied or unsatisfied customer. As per the 
research studies done by Geyser et al ( 2016 ) identified that, in hospitality culinary is an art from a training perspective, is a positive experience, a phenomenon which has not yet been explored in a comprehensive and systematic manner. Based on the studies and reflection that was identified by Enema, et al (2016) shows that Gap 2 and 3 error can be corrected in this work through staff training, making them to have a background knowledge of the culture of the hotel and what it stands for making them to understand how important it is to satisfy a guest beyond their expectations. This shows that training is one of the important and fundamental aspects by the hospitality stakeholders and the concern department to meet the customers' expectations by equipping the hotel employees to give out the best service.

\subsubsection{E- Learning}

As per the research done by Rimale et al (2016), states that E-Learning is a process that takes advantage of the use of information technology and communication at all levels of the training activity. It ideally focuses to a training program whose main objectives can be defined as independent learning, distance learning, individualized training courses and development of educational relationships online. According to Kumar (2013), E- Learning is the use of knowledge that is distributed and facilitated by electronic means of web based, multimedia CD- ROMs, websites, discussion boards, collaborative software, emails, blogs, wikis, test chat, simulation games and educational animation. E- Learning is a learning method that is shared within the domain of users, by downloading the course material and accessing it from anywhere by the means of computer devices, linked with the organization through the internet. The widespread use of internet has helped the users to share the material during and after their learning process. It is a gate way to the other part of the world, where different types of course can be accessed by live streaming and users learn according to their convenient time. E- Learning can be more flexible by keeping the complete data stored and the accessing the material and studying the material later as per their convenience. To get connected to the other part of the world, E- Learning is one of the best ways to grab and share the knowledge. It is a real time and self-paced learning method which is to be "synchronous" or "asynchronous" learning method that is presented in a formal and structured manner. E- Learning is one of the best ways of learning through the means of computer and internet. In a broader sense, E-Learning is conducted through an electronic model by delivering and teaching. The great power of E-Learning has had a major impact on the information technology. E- Learning is the convergence method that has been brought to the internet, where people can share and access from anywhere in the world. They can customize and plan accordingly to learn and train themselves. The user can get the information through the internet sources by downloading the training material or the specific content from his home or even during the training sessions. This can be done by getting the information and learning the content via compact disc, Videos, You-Tube as live streaming, live video conference. This piece of training and learning can be stored as digital libraries in the main server of the information technology department of the respective hotels. (Chaudhary 2012). The basic principle of E- Learning is connectivity that comprises: defining the system, encouraging access, advising and providing assistance to the individual learners by encouraging and facilitating the creation of learning environments in an asynchronous process. This process is 
endorsed to be one of the most efficient methods of training the employees as self-paced and learner - centric. According to Chore Elfish (2016) E-learning is considered a new form of individual learning, which may be seen as a new individual learning tool likely to spread knowledge and thus promote organizational learning. New educational and training technologies can take individuals as the main focus by using the platform of teleconferencing and videoconferencing experiences and information exchange through emails, chats or forums testify to this fact. This mode of learning will add on to the training effects in the hotel industry and the concern departments which directly or indirectly reduce the cost of travelling cost of the managers.

\subsubsection{Current Scenario of E- Learning}

Now, the Indian hotel industry is pooled with several international hotels chain as well as Indian-owned hotel chains. The country is not only having foreign tourists but also domestic tourist. Development of heritage and boutique hotels can be seen in places like Rajasthan and outskirts of Delhi. Many measures are taken by both Central and State Government to market the Goa and Kerala beaches. As Armstrong (2009), comments: " Today the approach is to focus on individual learning and ensure that it takes place when required - 'just-for-you' and 'just-in-time' learning." E- Learning is a way for staff to improve their capabilities and achieve greater job satisfaction, says Adrian Murton (2010). ELearning is carefully tailored to the organization's objectives and need of the employees should also be taken into consideration. According to ASTD report, E-Learning is highly preferred by workers under the age of 30 years (American Society of Training and Development). Studies from Deeply Paned, V. M. Wada \& V. M. Thake (2016) have shown that, growth rate shows how each country adopts eLearning and is a significant indicator since it can reveal revenue opportunities. The growth rate of self-paced E-Learning by country is that India has 55\%,China with 52\%, Malaysia with $41 \%$, Romania with $38 \%$, Poland with28\%, Czech Republic with 27\%; Brazil with 26\% Indonesia with 25\%,Colombia with $20 \%$ and Ukraine with $20 \%$ of usage of E- learning. It was identified by the above researchers that India is one of the major leading information technology service provider countries. The presence of world class IT infrastructure and IT professionals enable it to be one of the leading E- Learning service providers in India. The government is taking proactive measures I regulatory and financial capacity to boost the E-Learning environment in India.

\section{Methodology}

The researcher attempts to get the corporate employees insight on the training methods used and impact of E-training in the hospitality industry. The population for this study is the employees from corporate groups of four and five star hotels located in Tamil Nadu and listed under the Federation of Hotel and Restaurant Associations of India (FHRAI). There were 25 hotels belonging to 17 corporate groups of hotels which are listed by FHRAI with the star classification, segment classification and the corporate groups. The sampling procedure involved the selection of four and five star corporate group hotels classified under FHRAI in Tamil Nadu and should be rated as four and five star category by the Hotel and Restaurants Approval and Classification Committee (HRAAC). This is a descriptive study which collects 


\section{Macrothink}

International Journal of Human Resource Studies

ISSN 2162-3058 2016, Vol. 6, No. 2

the data to determine the perception towards E-Learning, ways of promoting E-Learning in the hospitality industry. Convenience sampling was adopted for the employees' survey. The questionnaires were received from 121 employees of 15 corporate hotel groups.

\section{Results}

Table 1. Sub sample of the respondents- Manager

\begin{tabular}{|l|l|l|l|}
\hline \multirow{2}{*}{ Description } & Category & Frequency & Percent \\
\hline \multirow{2}{*}{ Segmentation } & Segment 1 & 47 & 62.67 \\
\cline { 2 - 4 } & Segment 2 & 28 & 37.33 \\
\hline \multirow{2}{*}{ Star Category } & Four-Star & 28 & 37.33 \\
\cline { 2 - 4 } & Five-Star & 47 & 62.67 \\
\hline
\end{tabular}

For doing this analysis, the respondents from the managers are categorized in three ways:

Segmentation: The managers are divided into two segments. Segment 1: Those working in corporate hotel groups having properties within India. Segment 2: Those working in corporate hotel groups having properties both in India and abroad. Star Category: The managers are divided depending on the star category of the hotels they worked, either four-star hotels or five star hotels. 75 managers responded to the survey questionnaire of the managers. Table No 1 shows the segmentation of the hotels. The hotels are taken from the listing of the FHRAI 2012. 62.67 percent of the respondents are managers from segment 1 hotel groups and 37.33 percent of the respondents are managers from segment 2 hotel groups. In terms of star category, 37.33 percent of the managers are from four-star hotels whereas 62.67 percent of the managers are from five-star or five-star deluxe properties.

Table 2. Role of training managers in the successful implementation of E-Learning as a training medium in the hospitality industry -Manager's perspective 


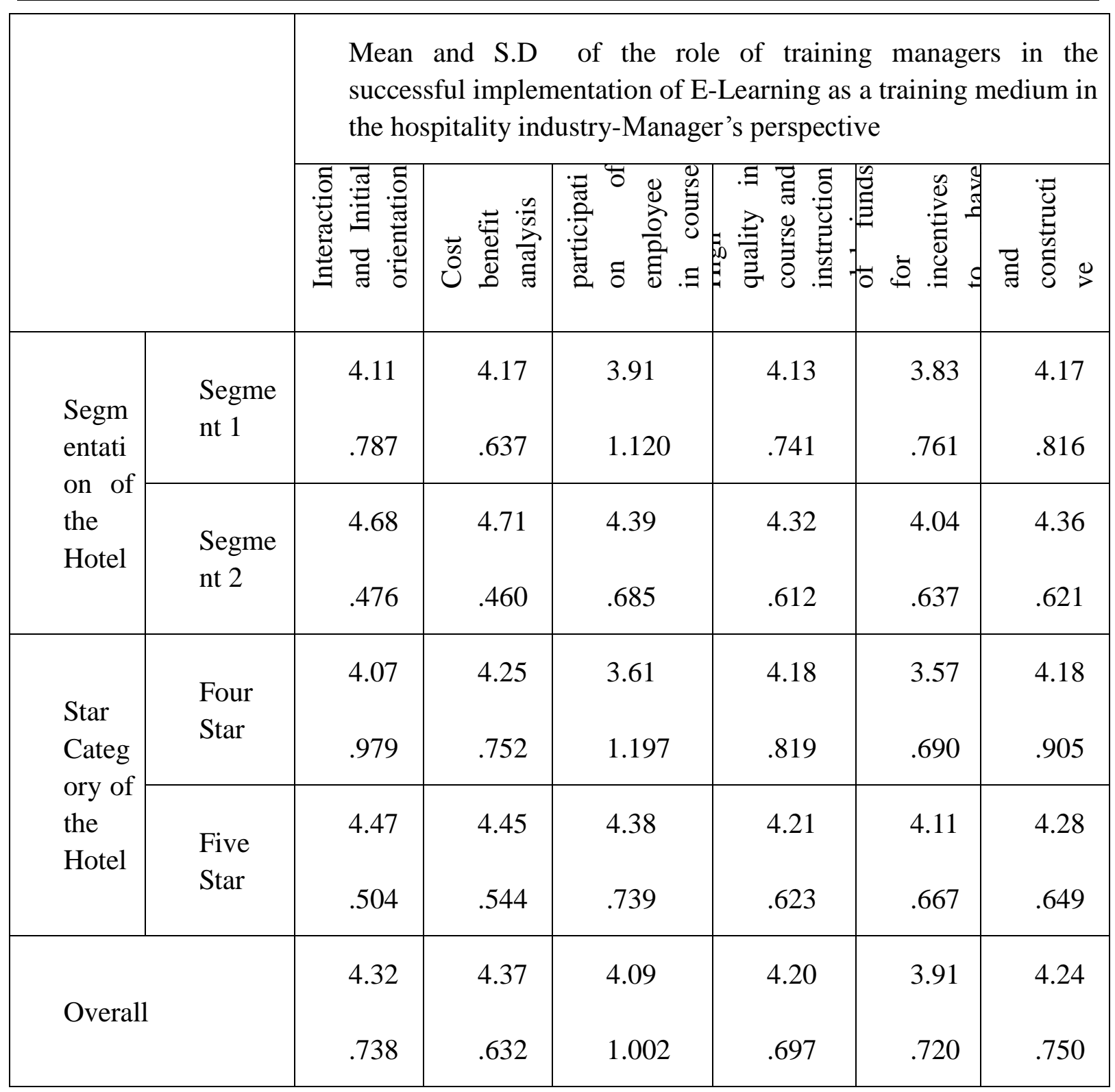

Overall, the hotel managers have rated cost benefit analysis, interaction and initial orientation and honest and constructive feedback as the top three roles of training managers for the successful implementation of E-Learning with a mean score of 4.37, 4.32 and 4.24 respectively. Under segment category, segment 1 hotel managers have opined that cost benefit analysis, high quality in course and instructional design and interaction and initial orientation as the top three important roles of training managers in successful implementation of E-Learning as a training medium with a mean score of 4.17, 4.13 and 4.11 respectively. Segment 2 hotel managers have rated that cost benefit analysis, interaction and initial orientation and active participation of employee in course design to be the top three important roles of training managers in successful implementation of E-Learning as a training medium with a mean score of 4.71, 4.68 and 4.40 respectively. Under star category, the four star hotel managers have rated cost benefit analysis, high quality in course and instructional design and honest and constructive to be the top three important roles of training managers in successful implementation of E-Learning as a training medium with a mean score of 4.24, 4.18 and 4.18 
respectively. The managers of five star hotels have rated interaction and initial orientation, cost benefit analysis and active participation of employee in course design feedback as the top three roles of the training manager for the successful implementation of E-Learning with a mean score of $4.47,4.45$ and 4.39 respectively.

Table 3. Role of dapartment managers in the successful implementation of E-Learning as a training medium - Managers Perspective.

\begin{tabular}{|c|c|c|c|c|c|c|}
\hline & & \multicolumn{5}{|c|}{$\begin{array}{l}\text { Mean and S.D of role of Department managers in } \\
\text { successful implementation of E-Learning as a training } \\
\text { medium in the hospitality industry-Manager's } \\
\text { perspective }\end{array}$} \\
\hline & & 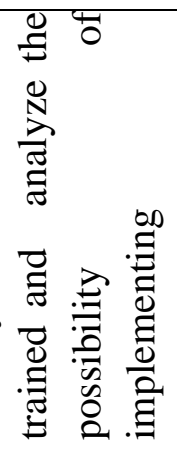 & 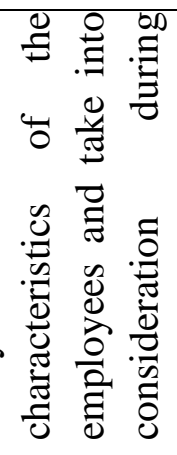 & 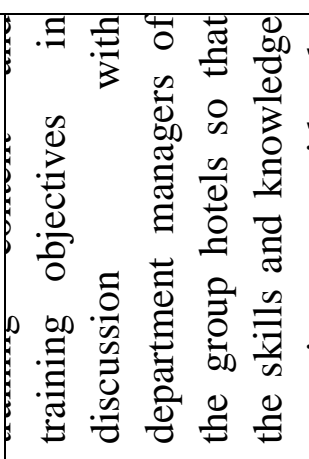 & 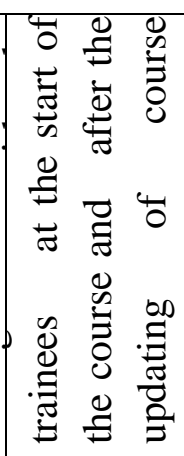 & 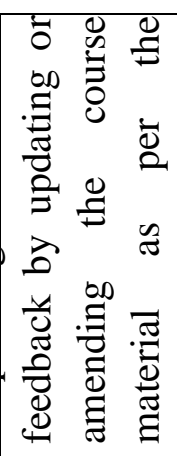 \\
\hline \multirow{2}{*}{$\begin{array}{l}\text { Segmenta } \\
\text { tion of the } \\
\text { Hotel }\end{array}$} & $\begin{array}{l}\text { Segme } \\
\text { nt } 1\end{array}$ & $\begin{array}{l}4.06 \\
.895\end{array}$ & 4.15 & 4.15 & $\begin{array}{l}4.28 \\
.743\end{array}$ & $\begin{array}{l}4.06 \\
.845\end{array}$ \\
\hline & $\begin{array}{l}\text { Segme } \\
\text { nt } 2\end{array}$ & $\begin{array}{l}3.96 \\
.962\end{array}$ & 4.36 & $\begin{array}{l}3.96 \\
.744\end{array}$ & $\begin{array}{l}4.32 \\
.772\end{array}$ & $\begin{array}{l}4.14 \\
.651\end{array}$ \\
\hline \multirow{2}{*}{$\begin{array}{l}\text { Star } \\
\text { Category } \\
\text { of the } \\
\text { Hotel }\end{array}$} & $\begin{array}{l}\text { Four } \\
\text { Star }\end{array}$ & .832 & .720 & 4.00 & 4.07 & .744 \\
\hline & $\begin{array}{l}\text { Five } \\
\text { Star }\end{array}$ & .961 & .673 & .711 & .683 & $\begin{array}{l}4.13 \\
.797\end{array}$ \\
\hline \multicolumn{2}{|l|}{ Overall } & $\begin{array}{l}4.03 \\
.915\end{array}$ & 4.23 & $\begin{array}{l}4.08 \\
.801\end{array}$ & 4.29 & $\begin{array}{l}4.09 \\
.774\end{array}$ \\
\hline
\end{tabular}




\section{Al Macrothink}

International Journal of Human Resource Studies

ISSN 2162-3058 2016, Vol. 6, No. 2

Overall, the hotel managers have rated orientation to the trainees at the start of the course and after the updating of course material, analyze the characteristics of the employees and take into consideration during course design and responding to the feedback by updating or amending the course material as per the requirement as the top three roles of department managers for the successful implementation of E-Learning with a mean score of 4.29, 4.23 and 4.09 respectively. Under segment category, segment 1 hotel managers have opined, giving orientation to the trainees at the start of the course and after the updating of course material, analyze the characteristics of the employees and take into consideration during course design and regular updating of the training content and training objectives in discussion with department managers of the group hotels so that the skills and knowledge are in par with the industry requirement as the top three important roles of department managers in successful implementation of E-Learning as a training medium with a mean score of $4.28,4.15,4.15$ respectively. Segment 2 hotel managers have rated analyze the characteristics of the employees and take into consideration during course design, giving orientation to the trainees at the start of the course and after the updating of course material and responding to the feedback by updating or amending the course material as per the requirement to be the top three important roles of department managers in successful implementation of E-Learning as a training medium with a mean score of 4.36, 4.32 and 4.14 respectively. Under star category, the four star hotel managers have rated, giving orientation to the trainees at the start of the course and after the updating of course material, responding to the feedback by updating or amending the course material as per the requirement and analyze the characteristics of the employees and take into consideration during course design as the top three roles of the department managers for the successful implementation of E-Learning with a mean score of 4.07, 4.04 and 4 respectively. The managers of five star hotels have rated giving orientation to the trainees at the start of the course and after the updating of course material, analyze the characteristics of the employees take into consideration during course design and regular updating of the training content and training objectives in discussion with department managers of the group hotels so that the skills and knowledge are in par with the industry requirement as the top three roles of the training manager for the successful implementation of E-Learning with a mean score of 4.43, 4.36 and 4.13 respectively.

Table 4. Opinion about the current scenario of E-Learning as a training medium in the hospitality industry - Manager's perspective. 


\begin{tabular}{|c|c|c|c|c|c|}
\hline \multirow{2}{*}{$\begin{array}{l}\text { Opinion about the current } \\
\text { scenario of E- Learning as a } \\
\text { training medium in the } \\
\text { hospitality industry }\end{array}$} & \multicolumn{5}{|c|}{ Frequency (Percent ) } \\
\hline & $\begin{array}{l}\text { Segment } \\
1\end{array}$ & $\begin{array}{l}\text { Segment } \\
2\end{array}$ & $\begin{array}{l}\text { Four } \\
\text { Star }\end{array}$ & $\begin{array}{l}\text { Five } \\
\text { Star }\end{array}$ & Overall \\
\hline $\begin{array}{l}\text { E- Learning is have used in all } \\
\text { the areas where training is } \\
\text { required }\end{array}$ & $\begin{array}{l}15 \\
(20)\end{array}$ & $\begin{array}{l}5 \\
(6.67)\end{array}$ & $\begin{array}{l}9 \\
(12)\end{array}$ & $\begin{array}{l}11 \\
(14.67)\end{array}$ & $\begin{array}{l}20 \\
(26.67)\end{array}$ \\
\hline $\begin{array}{l}\text { Usage of E- Learning is } \\
\text { rapidly increasing }\end{array}$ & $\begin{array}{l}5 \\
(6.67)\end{array}$ & $\begin{array}{l}14 \\
(18.67)\end{array}$ & $\begin{array}{l}5 \\
(6.67)\end{array}$ & $\begin{array}{l}14 \\
(18.67)\end{array}$ & $\begin{array}{l}19 \\
(25.33)\end{array}$ \\
\hline $\begin{array}{l}\text { E- Learning is slowly } \\
\text { implemented in all the } \\
\text { training areas, wherever } \\
\text { possible }\end{array}$ & $\begin{array}{l}17 \\
(22.67)\end{array}$ & $\begin{array}{l}5 \\
(6.67)\end{array}$ & $\begin{array}{l}9 \\
(12)\end{array}$ & $\begin{array}{l}13 \\
(17.33)\end{array}$ & $\begin{array}{l}22 \\
(29.33)\end{array}$ \\
\hline $\begin{array}{l}\text { Usage of E- Learning as a } \\
\text { training medium is minimal }\end{array}$ & $\begin{array}{l}7 \\
(9.33)\end{array}$ & $\begin{array}{l}0 \\
(0)\end{array}$ & $\begin{array}{l}4 \\
(5.33)\end{array}$ & $3(4)$ & $\begin{array}{l}7 \\
(9.33)\end{array}$ \\
\hline Not have used at all. & $\begin{array}{l}1 \\
(1.33)\end{array}$ & $\begin{array}{l}0 \\
(0)\end{array}$ & $\begin{array}{l}0 \\
(0)\end{array}$ & $\begin{array}{l}1 \\
(1.33)\end{array}$ & $\begin{array}{l}1 \\
(1.33)\end{array}$ \\
\hline $\begin{array}{l}\text { E- Learning is have used in all } \\
\text { the areas where training is } \\
\text { required and is slowly } \\
\text { implemented in all the } \\
\text { training areas, wherever } \\
\text { possible }\end{array}$ & $\begin{array}{l}2 \\
(2.67)\end{array}$ & $\begin{array}{l}0 \\
(0)\end{array}$ & $\begin{array}{l}0 \\
(0)\end{array}$ & $\begin{array}{l}1 \\
(1.33)\end{array}$ & $\begin{array}{l}1 \\
(1.33)\end{array}$ \\
\hline $\begin{array}{l}\text { E- Learning is have used in all } \\
\text { the areas where training is } \\
\text { required and usage is minimal }\end{array}$ & $\begin{array}{l}0 \\
(0)\end{array}$ & $\begin{array}{l}3 \\
(4)\end{array}$ & $\begin{array}{l}0 \\
(0)\end{array}$ & $\begin{array}{l}3 \\
(4)\end{array}$ & $\begin{array}{l}3 \\
(4)\end{array}$ \\
\hline $\begin{array}{l}\text { E- Learning is have used in all } \\
\text { areas where training required, } \\
\text { slowly implemented in all } \\
\text { training areas and usage of E- } \\
\text { Learning is minimal }\end{array}$ & $\begin{array}{l}0 \\
(0)\end{array}$ & $\begin{array}{l}1 \\
(1.33)\end{array}$ & $\begin{array}{l}1 \\
(1.33)\end{array}$ & $\begin{array}{l}1 \\
(1.33)\end{array}$ & $\begin{array}{l}2 \\
(2.67)\end{array}$ \\
\hline
\end{tabular}


Under segment classification, 20 percent of segment 1 employees and 6.67 percent of segment 2 employees have opined that E-Learning is used in all the areas where training is required. 6.67 percent of segment 1 employees and 18.67 percent of segment 2 employees have rated the usage of E-Learning is rapidly increasing, 22.67 percent of segment1 employees and 6.67 percent of segment 2 employees have opined that E-Learning is slowly implemented in all the training areas, wherever possible, 9.33 percent of the segment 1 employees have opined that the usage of E-Learning as a training medium is minimal. 1.33 percent of segment 1 employees have rated that E-Learning is not have used at all, 2.67 percent of segment 1 employees have rated E-Learning is have used in all the areas where training is required and usage of E-Learning is rapidly increasing. 1.33 percent of segment 2 employees have rated that E-Learning is slowly implemented in all the training areas, wherever possible and usage of E-Learning as a training medium is minimal. Under star classification, 12 percent of employees working in four-star hotels and 14.6 percent of employees working in five-star hotels have opined that E-Learning is have used in all the areas where training is required. 6.67 percent of employees working in four-star hotels and 18.67 percent of employees working in five-star hotels have opined that usage of E-Learning is rapidly increasing. 12 percent of employees working in four-star hotels and 17.33 percent of employees working in five-star hotels have opined that E-Learning is slowly implemented in all the training areas, wherever possible. 5.33 percent of employees working in four-star hotels and 4 percent of employees working in five-star hotels have opined that usage of E-Learning as a training medium is minimal. 1.33 percent of employees working in five-star hotels have rated that E-Learning is not have used at all. 1.33 percent of employees working in five-star hotels have rated that E-Learning is have used in all the areas where training is required and is slowly implemented in all the training areas, wherever possible. 4 percent of employees working in five-star hotels have rated that E- Learning is have used in all the areas where training is required and usage is minimal. 1.33 percent of employees working in four-star hotels and 1.33 percent of employees working in five-star hotels have opined that E-Learning is have used in all areas where training required, slowly implemented in all training areas and usage of E-Learning is minimal.

\section{Conclusion}

Overall, the hotel managers has rated cost benefit analysis, interaction and initial orientation and honest and constructive feedback as the top three roles of training managers for the successful implementation of E-Learning as a training medium. Cost benefit analysis has rated by all the managers for the successful implementation of E-Learning as a training medium. Cost benefit analysis which is the process of determining the economic benefits of training program using accounting methods that look at training costs and benefits. (Raymond Noe 2008).It helps the training manager to explain the productiveness of the training program and leads to the successful implementation of E-Learning as a training medium. Cost benefit analysis has been rated by all the managers irrespective of the category. By tracking the department training data, the managers can demonstrate the worth of training by showing how its service quality change due to training, contribute to the hospitality business. This cost benefit analysis also made the upper management to provide financial 
resources. Interaction and initial orientation is rated as one of the top three attributes which describes the role of the training manager in the successful implementation of E-Learning as a training medium. Interaction can also be verbal persuasion which means offering words of encouragement to convince others they can learn. The training manager has to identify the positive outcome of the training, interact with the trainees to link the positive outcome of the training to the learners' acquiring knowledge or skills or changing behavior. This will enhance the user acceptance of the training. Honest and constructive feedback has been rated as one of the top three roles of the training managers for the successful implementation of E-Learning as a training medium. The objective of the training can be achieved by honest and constructive feedback. Feedback will enhance about the need of the management and employees and steps that have to be taken to improve the training outcomes. Feedback will bridge the gap between the trainer and the trainee, and helps to get better results for training. The main role of the training manager is to help company values and philosophy and ensures all training and development activities are strategically linked to the organization's mission and vision.

To analyze the characteristics of the employees and take into consideration during course design, giving orientation to the trainees at the start of the course and after the updating of course material and responding to the feedback by updating or amending the course material as per the requirement are proven to be the top significant role of the department managers for the successful implementation of E-Learning. So by giving the orientation at the start of the training or after any major updates provides the trainee with the basic background information about the training and awareness about the objective of the training. It moreover familiarizes the trainees to master the necessary skills to undergo training efficiently by reducing the trainees' anxiety and reinforces favorable impression about the training and makes it more productive and efficient. The growth of E-Learning is highly influenced by the decreasing cost of the training. E-Learning needs lot of responsibility from the user but simultaneously gives freedom to the user. With the technology advancement in information and communication, delivering various training module and updating the content has become easier.

\section{Acknowledgement}

We would like to take this opportunity to thank our Prof. Dr. B. Rajasekeran, Professor \& Head, Department of Management Studies, Monomaniam Sundaranar University, Tamil Nadu, India for guiding and supporting in this research work

\section{References}

Adrain Murton, Margaret Inman \& Nuala O Sulivan (2010), Unlocking: Human Resource Management, London, UK, Hodder Education

Armstrong. M (2009) Armstrong's Handbook of Human Resource Management Practice, London, UK: Kogan Page

Aravamudhan,N.R \& Krishnaveni. R (2015) Establishing and reporting content validity evidence of new training and development capacity building scale.Journal of Contemporary 
Management Issues. Vol. 20, 2015, 1, pp. 131-158 ISSN 1846-3363 (Online), http://www.efst.hr/management.

Chaudhary (2012) Active Have used of Digital Library for E- Learning in India. JOURNAL OF INDIAN LIBRARY ASSOCIATION 2012, 48(1) -24-27 Vol. XLVIII, No 1, January-March, 2012.

Chokri Elfidha (2016). An Assessment of the Impact of the Use of New Technologies on the Learning Quality: The Case of Tunisian National Post Office (NPO) E-Learning School. Proceedings of Los Angeles International Business and Social Science Research Conference, Garland Hotel, North Hollywood, California, USA, 5-7 March, 2016; ISBN 978-0-9942714-6-4. Retrieved on $13^{\text {th }}$ May 2016.

Brinia. V. \& Alexandra. K.C.(2016). In-Company Training In Tourism: The Case of the Domotel Hotels and Resorts. International Journal of Human Resource Studies. Vol. 6, No. 2. ISSN 2162-3058. doi:10.5296/ijhrs.v6i2.9258. Macrothink Institute.

Chilembwe, J. M., \& Baluti, J. (2014). Motivation and supervision in the hospitality industry with focus to hotels and lodges in Mzuzu city. International Journal of Social Sciences and Entrepreneurship, 1(10), 1-13.

Deepali Pande, V. M. Wadhai \& V. M. Thakre (2016). Current trends of E-learning in India. International Research Journal of Engineering and Technology. Volume: 03 Issue:1. -ISSN: 2395 -0056. www.irjet.net.

Debra F.Cannon \& Catherine M. Gustafson.(2002), Training and Development for the Hospitality Industry, USA: Educational Institute of the American Hotel \& Lodging Association, Page no 4,7,13,39,41,44,62

Enz, C. A. (2009). Human Resource Management: A Troubling Issue for the Global Hotel Industry , Cornell Hospitality Quarterly November 2009 50: 578-583, first published on October 23, 2009 doi:10.1177/1938965509349030.

Enemuo, O. B., Ejikeme, J. N. U. and Edward, C.(2016) The role of customer satisfaction and maintenance culture in the sustainability of hospitality industries in Umuahia North and South Local Government Areas of Abia State. Journal of Hospitality and Management Tourism. Vol. 7(1), pp. 1-10,. ISSN 2141-6575. http://www.academicjournals.org/JHMT DOI: $10.5897 / \mathrm{JHMT} 2015.0164$.

Ferguson I.L (2008) The Impact Of Training And Development On Worker Performance And Productivity In Public Sector Organizations: A Case Study Of Ghana Ports And Harbors Authority.

Geyser.I, Crous.F \& Geldenhuys.M (2016). Mise en place: time management behaviour and flow within the hospitality training environment. African Journal of Hospitality, Tourism and Leisure Volume 5 (1) - (2016) ISSN: 2223-814X. Copyright: @ 2016 AJHTL - Open AccessOnline @ http//:www.ajhtl.com.

Kumar. S. (2013) E- and M- Learning: A Comparative study, International Journal on New 
Trends in education and Their Implications. Volume: 4 Issue: 3 Article :) 08 ISSN 1309-6249.

Kye-Sung (Kye) Chon \& Raymond T. Sparrowe (2000) Welcome to Hospitality: An introduction; USA. Delmar is a division of Thomson Learning. ISBN: 0-7668-0850-5

Leena Kakkar\& Sapna (2012) Impact of Tourism on Indian Economy. International Journal of Marketing, Financial Services \& Management Research. Vol.1 No. 4, April 2012, ISSN 22773622

Raymond A Noe (2008) Employee Training and Development, Fourth Edition, Tata McGraw - Hill Publishing Company Limited.

Rimale Zouhair, Ben lahmar El habib,\& Tragha Abderrahim (2016). A Brief Survey and Comparison of m-Learning and e-Learning. International Journal of Computer Networks and Communications Security. Vol. 4, No. 4 p.85-95. E-ISSN 2308-9830. www.ijcncs.org.

\section{Glossary}

ASTD: American Society of Training and Development

CD- ROMs: Compact Disc- Read Only Memory

FHRAI: Federation of Hotels Restaurant Association of India

GRT: G.Rajendran Thanga Maligai

HRAAC: Hotel and Restaurants Approval and Classification Committee

SHRAI:South India Hotel Restaurant Association of India.

\section{Copyright Disclaimer}

Copyright for this article is retained by the author(s), with first publication rights granted to the journal.

This is an open-access article distributed under the terms and conditions of the Creative Commons Attribution license (http://creativecommons.org/licenses/by/3.0/). 